\title{
Bilateral thoracic paravertebral nerve blocks for placement of percutaneous radiologic gastrostomy in patients with amyotrophic lateral sclerosis: a case series
}

\author{
Arun Kalava ${ }^{1,2}$, Steven Clendenen ${ }^{1}, \mathrm{~J}_{\text {Mark McKinney }}{ }^{1}$, Elird Bojaxhi ${ }^{1}$, Roy A Greengrass ${ }^{1}$
}

${ }^{1}$ Department of Anesthesiology, Mayo Clinic, Jacksonville, FL, USA

${ }^{2}$ Department of Anesthesiology, Tampa General Hospital, Tampa, FL, USA

\begin{abstract}
Background and Aims: To assess the efficacy of bilateral thoracic paravertebral nerve blocks (PVB) in providing procedural anesthesia and post-procedural analgesia for placement of percutaneous radiologic gastrostomy tubes (PRG) in patients with amyotrophic lateral sclerosis (ALS).

Methods: We prospectively observed 10 patients with ALS scheduled for PRG placement that had bilateral thoracic PVBs at thoracic 7, 8, and 9 levels with administration of a mixture of $3 \mathrm{~mL}$ of $1 \%$ ropivacaine, $0.5 \mathrm{mg} / \mathrm{mL}$ dexamethasone, and $5 \mu \mathrm{g} / \mathrm{mL}$ epinephrine at each level. The success of the block was assessed after 10 minutes. PRG placement was done in the interventional radiology suite without sedation. All patients were followed up via phone 24 hours after the procedure.

Results: All 10 patients had successful placement of PRG with PVBs as the primary anesthetic. Segmental anesthesia over the surgical site in all cases was successful with first attempt of the blocks. Three patients had significant hypotension after the block, requiring boluses of vasopressors and intravenous fluids. All patients reported high levels of satisfaction and sleep quality on the night of the procedure.

Conclusions: Bilateral thoracic PVBs provided satisfactory procedural anesthesia and post-procedural analgesia, and thus, seem promising as a safe alternative to sedation in ALS patients having PRG placement.

Keywords: thoracic paravertebral nerve blocks, percutaneous radiological gastrostomy, amyotrophic lateral sclerosis
\end{abstract}

\section{Introduction}

Enteral nutrition is provided in patients with advanced amyotrophic lateral sclerosis (ALS) who have bulbar symptoms. Percutaneous radiological gastrostomy (PRG) is a safe and effective method of nutritional tube placement in these patients [1,2]. PRG is performed either under local anesthesia infiltration analgesia, with or without mild sedation, or general anesthesia [2]. Respiratory depressant effects of sedative medications $[3,4]$ are pronounced in these patients,

Adress for correspondence:

Arun Kalava, MD

Tampa General Hospital

1 Tampa General Cir, Suite A 327

Tampa, FL 33606 USA

E-mail: arun_kalava@teamhealth.com and they are to be used judiciously or avoided altogether while placing a PRG. Peri-stomal pain during and after a PRG [2] placement has been inadequately addressed [5]. We believe that local anesthetic infiltration provides insufficient analgesia both during and after the procedure as the procedure entails piercing skin, abdominal wall muscles, peritoneum, and the stomach wall.

Paravertebral nerve blocks (PVB) have been used to provide analgesia for surgical procedures, trauma, and chronic pain [6] and have been used to produce procedural anesthesia in patients undergoing minimality invasive abdominal procedures such as liver mass radiofrequency ablation [7], percutaneous transhepatic biliary drainage [8], and percutaneous nephrolithotomy [9]. We report a series of patients with ALS who underwent PRG placement under bilateral thoracic PVBs. 


\section{Methods}

This was a prospective observational case series of patients who were diagnosed with ALS and had significant bulbar symptoms requiring placement of a PRG. An institutional Review Board approval was not required given the small sample size.

The inclusion criteria were all patients with ALS who had bulbar symptoms and had been deemed candidates for placement of PRG by the neurologist at our institute due to progressive malnourishment and decreased oral intake with a high risk of pulmonary aspiration.

Patients who had contraindications to performance of PVBs, i.e., infection at the block site, tumors in the paravertebral space at the level of injection, allergy to local anesthetic drugs, or patient refusal, were excluded.

All patients were referred from the Department of Neurology to the Department of Anesthesiology's Regional Anesthesia and Acute Pain Service prior to having a PRG. Patients were advised to remain nil per oral for more than 8 hours prior to their arrival to the hospital. An informed consent for performance of thoracic PVBs was obtained from each patient. Patients and their families were informed that these PVBs were a novel technique and their efficacy was being assessed based upon the outcome of the procedure and the experience they, the patients, would report to us when we give them a phone call the day after the procedure.

\section{Procedural technique}

All patients had an intravenous line placed by a nurse, and a pulse oximeter, non-invasive blood pressure, and five lead electrocardiograms were applied (standard American Society of Anesthesiologists monitors). A nasal cannula with oxygen flowing at 2-4 liters/minute was then administered.

All multiple thoracic PVBs were performed by a consultant regional anesthesiologist and/or a fellow in regional anesthesiology with the patient sitting up and hunched forward, while an assistant was holding the patient from the front using the traditional landmark technique. Thoracic spinous processes 6 to 8 were identified by palpating the inferior tip of the scapula, which anatomically corresponds to the $\mathrm{T} 7$ spinous process. As injection of a larger volume local anesthetic at fewer levels (i.e., bilateral T7 PVBs) resulted in an unpredictable spread in our experience therefore the local anesthetic was divided to be injected among three levels bilaterally (T7-9). A marking pen was used to mark the spinous process of $\mathrm{T} 6, \mathrm{~T} 7$, and $\mathrm{T} 8$, and the point of needle entry was marked $2.5 \mathrm{~cm}$ lateral to the superior aspect of these spinous processes bilaterally. These spinous processes correspond to thoracic spinal nerve roots 7, 8, and 9. Small incremental doses of $1 \%$ propofol (20-100 mg) were used to sedate the patients, as needed. The PVBs were performed in a sterile fashion after skin preparation was completed with Chloraprep ${ }^{\circledR}(2 \%$ chlorhexidine gluconate and $70 \%$ isopropyl alcohol). Local infiltration of skin was performed with $2 \%$ lidocaine $+1: 200,000$ epinephrine solution using a 25 Gauge hypodermic needle. A 22 Gauge 3.15 in $(8 \mathrm{~cm})$ Tuohy needle (B. Braun Medical Inc., Bethlehem, PA, USA) incremented every $1 \mathrm{~cm}$ was introduced $2.5 \mathrm{~cm}$ lateral to the palpated spinous process, approaching perpendicular to the skin, until contact with the transverse process was made. The needle was then withdrawn and redirected in caudad direction. It was then walked off the transverse process and advanced an additional depth of up to $1 \mathrm{~cm}$ until a loss of resistance through the superior costotransverse ligament (Figure 1) was appreciated. A $3 \mathrm{~mL}$ injectate containing a mixture of $1 \%$ ropivacaine $+0.5 \mathrm{mg} / \mathrm{mL}$ dexamethasone $+5 \mu \mathrm{g} / \mathrm{mL}$ epinephrine was then deposited in the paravertebral space after confirmation of no aspiration of blood or cerebral spinal fluid. After completion of the procedure, the success of the block was confirmed using loss of temperature sensation to ice in the corresponding dermatomes (i.e., T7, 8 and 9; Figure 2). After that, an 8FR enteral feeding tube (Corpak MedSystems Inc., Buffalo Gove, IL, USA) was inserted through one of the nostrils using a lubricating gel. This enteral feeding tube was placed to facilitate the insufflation of air into the stomach and to bring the stomach closer to the abdominal wall to aid the interventional radiologist. Patients were then transferred to an interventional radiology suite to have their feeding tubes placed. No sedation was administered for this procedure.

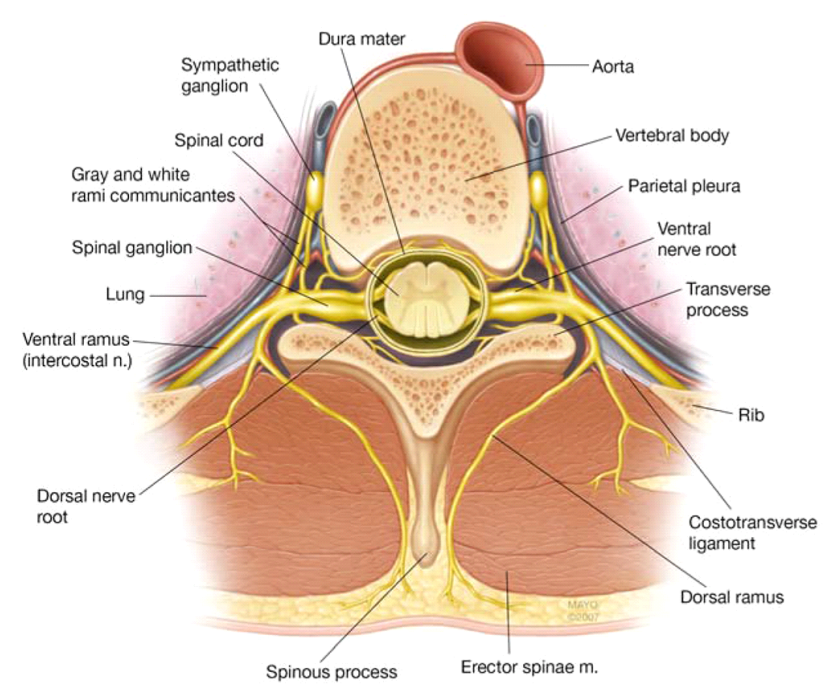

Fig. 1. Thoracic paravertebral space/costotransverse ligament (by permission of Mayo Foundation for Medical Education and Research. All rights reserved) 


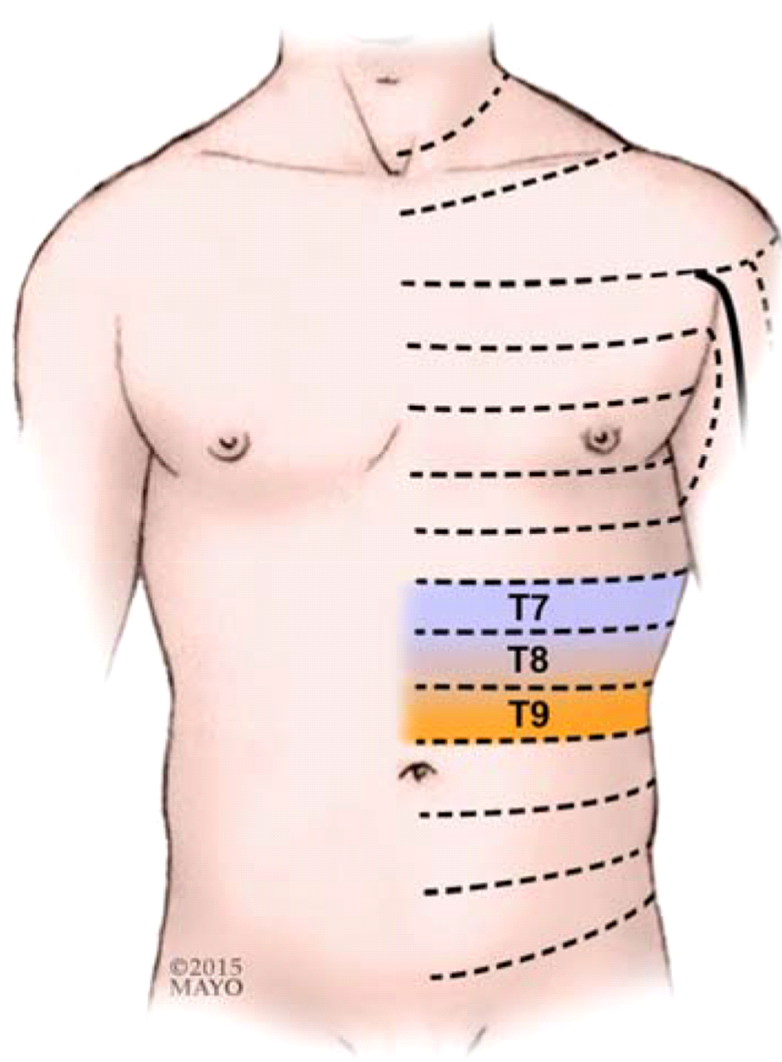

Fig. 2. Dermatomal anesthesia required for placement of percutaneous radiologic gastrostomy tubes (by permission of Mayo Foundation for Medical Education and Research. All rights reserved)

\section{Patient Follow-Up}

All patients were then followed up the day after the procedure via phone. Data was collected on the severity of pain (on a 0-10 numerical rating scale), analgesic requirements in the first 24 hours, the quality of sleep and the satisfaction with the pain control asked to be rated as poor/fair/good/very good/excellent (Table 1).

\section{Results}

The patients in this observational case series were all consecutive and did not have any contraindications regarding performing PVBs. All patients demonstrated thermal anesthesia to ice over the upper abdominal wall and underwent uneventful PRG placement. Three of the first four patients on whom these thoracic PVBs were performed, had a significant drop in blood pressure (more than $20 \%$ baseline) due to sympathectomy associated with these nerve blocks. These patients required boluses of phenylephrine 100-200 mcg and ephedrine 10-20 $\mathrm{mg}$ to maintain adequate blood pressure along with crystalloid and colloid infusions.

In view of hypotension due to sympathectomy form bilateral PVBs, the subsequent patients were given an intravenous bolus of $500 \mathrm{ml}$ of $5 \%$ Albumin immediately prior to performance of the PVBs. In doing this, we found that none of the patients experienced significant hypotension following the thoracic PVB with the albumin preloading. There were no complications [10], i.e., no epidural or intrathecal spread, pleural puncture, or pneumothorax were noted from the block.

On follow up at 24 hours post procedure, patients reported pain scores ranging from 0-7 and all patients reported high levels of satisfaction and sleep quality on the night of the procedure (Table 1).

\section{Discussion}

Local anesthetic infiltration of the skin and anterior abdominal wall prior to insertion of PRG is not sufficient to allay pain from the procedure. Patients with ALS are at a very high risk for respiratory compromise and aspiration, even when sedation is required during this procedure. With just the skin being anesthetized using local anesthetic infiltration, leaving the abdominal wall muscles and parietal peritoneum inadequately anesthetized, we believe that the incision, initial puncture, and dilation will result in significant pain [5].

Table 1. Pain scores, sleep quality, and satisfaction in patients

\begin{tabular}{|c|c|c|c|c|}
\hline Age/Sex & $\begin{array}{l}\text { Pain score }(0-10) \\
\text { after } 24 \text { hours }\end{array}$ & Analgesics used in first 24 hours & Sleep quality & $\begin{array}{c}\text { Overall satisfaction } \\
\text { with analgesia }\end{array}$ \\
\hline 72/Female & 0 & Hydrocodone/Acetaminophen 5/325 mg, 1 Tab & Good & Very good \\
\hline 62/Male & 0 & Hydrocodone/Acetaminophen 5/325 mg, 2 Tabs & Good & Excellent \\
\hline 71/Female & 5 & Hydrocodone/Acetaminophen 5/325 mg, $1 \mathrm{Tab}$ & Fair & Good \\
\hline 74/Male & 2 & None & Good & Excellent \\
\hline 60/Male & 7 & Ketorolac $30 \mathrm{mg}, 1 \mathrm{Tab}$ & Fair & Good \\
\hline 78/Male & 0 & None & Good & Excellent \\
\hline 62/Female & 1 & None & Very good & Excellent \\
\hline 64/Female & 6 & Hydrocodone $5 \mathrm{mg}, 1 \mathrm{Tab}$ & Good & Good \\
\hline 58/Male & 4 & Hydrocodone $5 \mathrm{mg}, 1 \mathrm{Tab}$ & Good & Very good \\
\hline $65 /$ Female & 1 & None & Very good & Good \\
\hline
\end{tabular}


The regional anesthetic options for PRG placement in this particular patient subgroup, to avoid untoward effects from sedation, are thoracic epidural, subarachnoid block (SAB), and PVBs. Thoracic epidural can reliably provide procedural anesthesia, but its limitations in these patients are that: i) the procedure is an outpatient based minor procedure; ii) dermatomal anesthesia obtained will, at times, be difficult to control as the spread of local anesthetic in the thoracic epidural space depends on a multitude of factors [11]; iii) compared to bilateral 3-level PVBs, the sympathectomy is more pronounced [12]; and iv) for it to provide postprocedural analgesia, an epidural catheter has to be inserted. SAB, though an option for procedures such as placement of percutaneous endoscopic gastrostomy tubes, would not be ideal as: i) it would cause a more significant sympathectomy and hypotension compared to bilateral 3-level PVB; ii) the duration of SAB and the anesthesia is limited ( $45 \mathrm{~min}$ to 3 hours) depending on the type of local anesthetic used; iii) it has no benefit from postoperative analgesia which can be obtained with PVBs, and iv) urinary retention and spinal headache [13] can be problematic, which can be avoided by using segmental PVBs targeting the dermatomes where the procedure would be performed. Not only do PVBs result in lesser sympathectomy than thoracic epidural and $\mathrm{SAB}$, they also avoid possible untoward complications such as epidural or spinal hematoma and spinal cord injury. Alternative regional anesthetic/analgesic options may potentially include subcostal Transversus Abdominis Plane (TAP) block [14] and/or rectus sheath block. However, there is a lack of evidence describing their use as a primary anesthetic in this patient population, and these blocks are unable to block visceral innervation from the peritoneum.

Local anesthetic adjuvants were also used to prolong the duration of the block. The density of the block and analgesic duration increases as the ropivacaine concentration increases [15], which influenced our choice to utilize $1 \%$ ropivacaine. Dexamethasone has been proven to prolong the block duration [16], and epinephrine attenuates the early phase of local anesthetic absorption.

Our ultimate goal in these patients was to provide superior anesthesia and post-procedural analgesia, avoiding medications that would potentially be detrimental in this subset of patients. Propofol has both sedative and amnestic effects [17], and due to its short time of action and short half-life, propofol leads to a much faster recovery after sedation [18]. We believe that the multiple injections the patients receive are very discomforting, and the best way to minimize the discomfort in these patients is with small doses of propofol. Mild sedation with propofol also helps the anesthesiologist by providing a still patient, making per- formance of a rather technically challenging PVB procedure (particularly in patients with ALS) less difficult, minimizing problematic complications that could result due to unexpected patient movement.

In light of the hypotension experienced by patients following the block, preloading or co-loading with crystalloids or colloids to avoid a significant drop in blood pressure due to sympathectomy from the block is often necessary. It is important to note that patients with advanced ALS are often dehydrated and malnourished when presenting for PRG placement and preemptive hydration is necessary. In our patients, preloading with colloids over crystalloid was chosen as intravascular half-life of colloids is anticipated to be longer. Albumin $5 \%$ was chosen (over i.e. hydroxyethyl starch) as it is the colloid commonly used at our institution for resuscitation.

All patients were very pleased with the analgesia provided and had uneventful placements of PRG which certainly supports bilateral thoracic PVBs as a strong alternative to local anesthesia infiltration with or without sedation. The drawbacks of this observational case series are that it is a single institute study, there is no randomization, the sample size is small for adequate power, the post-procedure analgesic regimen is not standardized, and the assessment of "quality of sleep" and "overall satisfaction" is fairly subjective. Further studies should be performed randomizing the patients to different concentrations of local anesthetics and additives, minimizing necessary PVB injection sites, and different regional techniques (i.e., subcostal TAP or rectus sheath block).

\section{Conclusion}

Thoracic PVBs, provided satisfactory procedural anesthesia and post-procedural analgesia in patients with ALS undergoing a PRG placement, and this technique is now routine practice at our institution.

\section{Conflict of interest}

Nothing to declare

\section{Acknowledgements}

There was no source of funding for this study. The authors would like to acknowledge Robert McClain, MD, Fellow, Regional Anesthesiology and Christopher Robards, MD, Assistant Professor of Anesthesiology, Mayo Clinic, FL for their support.

\section{References}

1. Chiò A, Galletti R, Finocchiaro C, Righi D, Ruffino MA, Calvo $A$, et al. Percutaneous radiological gastrostomy: a safe and effective method of nutritional tube placement in advanced ALS. J Neurol Neurosurg Psychiatry 2004; 75: 645-647 
2. Wollman B, D'Agostino HB, Walus-Wigle JR, Easter DW, Beale A. Radiologic, endoscopic, and surgical gastrostomy: an institutional evaluation and meta-analysis of the literature. Radiology 1995; 197: 699-704. DOI: 10.1148/radiology. 197.3.7480742

3. Hårdemark Cedborg AI, Sundman E, Bodén K, Hedström HW, Kuylenstierna R, Ekberg O, et al. Effects of morphine and midazolam on pharyngeal function, airway protection, and coordination of breathing and swallowing in healthy adults. Anesthesiology 2015; 122: 1253-1267. DOI: 10.1097/ALN. 0000000000000657

4. Boom M, Niesters M, Sarton E, Aarts L, Smith TW, Dahan A. Non-analgesic effects of opioids: opioid-induced respiratory depression. Curr Pharm Des 2012; 18: 5994-6004

5. Gutt CN, Held S, Paolucci V, Encke A. Experiences with percutaneous endoscopic gastrostomy. World J Surg 1996; 20 : 1006-1008; discussion 1008-1009

6. Greengrass RA, Duclas R Jr. Paravertebral blocks. Int Anesthesiol Clin 2012; 50: 56-73. DOI: 10.1097/AIA.0b013e318216c03e

7. Piccioni F, Fumagalli L, Garbagnati F, Di Tolla G, Mazzaferro V, Langer M. Thoracic paravertebral anesthesia for percutaneous radiofrequency ablation of hepatic tumors. J Clin Anesth 2014; 26: 271-275. DOI: 10.1016/j.jclinane.2013.11.019

8. Culp WC Jr, Culp WC. Thoracic paravertebral block for percutaneous transhepatic biliary drainage. J Vasc Interv Radiol 2005; 16: 1397-1400. DOI: 10.1097/01.RVI.0000174285. $84995.7 \mathrm{~F}$

9. Borle AP, Chhabra A, Subramaniam R, Rewari V, Sinha R, Ramachandran R, et al. Analgesic efficacy of paravertebral bupivacaine during percutaneous nephrolithotomy: an observer blinded, randomized controlled trial. J Endourol 2014; 28: 10851090. DOI: 10.1089/end.2014.0179

10. Naja Z, Lönnqvist PA. Somatic paravertebral nerve blockade. Incidence of failed block and complications. Anaesthesia 2001; 56: 1184-1188

11. Visser WA, Lee RA, Gielen MJ. Factors affecting the distribution of neural blockade by local anesthetics in epidural anesthesia and a comparison of lumbar versus thoracic epidural anesthesia. Anesth Analg 2008; 107: 708-721. DOI: 10.1213/ane.0b013e $31817 \mathrm{e} 7065$

12. Okajima H, Tanaka O, Ushio M, Higuchi Y, Nagai Y, Iijima K, et al. Ultrasound-guided continuous thoracic paravertebral block provides comparable analgesia and fewer episodes of hypotension than continuous epidural block after lung surgery. J Anesth 2015; 29: 373-378. DOI: 10.1007/s00540-014-1947-y

13. Longo S. Regional versus general anesthesia. Curr Opin Anaesthesiol 2000; 13: 539-543.

14. Hebbard PD, Barrington MJ, Vasey C. Ultrasound-guided continuous oblique subcostal transversus abdominis plane blockade: description of anatomy and clinical technique. Reg Anesth Pain Med 2010; 35(5): 436-441. DOI: 10.1097/ AAP.0b013e3181e66702

15. Finucane BT, Sandler AN, McKenna J, Reid D, Milner AL, Friedlander $\mathrm{M}$, et al. A double-blind comparison of ropivacaine $0.5 \%, 0.75 \%, 1.0 \%$ and bupivacaine $0.5 \%$, injected epidurally, in patients undergoing abdominal hysterectomy. Can J Anaesth 1996; 43: 442-449. DOI: 10.1007/BF03018104

16. Rasmussen SB, Saied NN, Bowens C Jr, Mercaldo ND, Schildcrout JS, Malchow RJ. Duration of upper and lower extremity peri- pheral nerve blockade is prolonged with dexamethasone when added to ropivacaine: a retrospective database analysis. Pain Med 2013; 14: 1239-1247. DOI: 10.1111/pme.12150

17. Veselis RA. The remarkable memory effects of propofol. Br J Anaesth 2006; 96: 289-291. DOI: 10.1093/bja/ael016

18. Carlsson U, Grattidge P. Sedation for upper gastrointestinal endoscopy: a comparative study of propofol and midazolam. Endoscopy 1995; 27: 240-243. DOI: 10.1055/s-2007-1005678

\section{Blocuri paravertebrale toracice bilaterale pentru plasarea gastrostomiei percutanate cu ghidaj radiologic la pacienți cu scleroză amiotrofică laterală: o serie de cazuri clinice}

\section{Rezumat}

Scop: Aprecierea eficacității blocurilor paravertebrale toracice (PVB) în asigurarea anesteziei procedurale şi analgeziei postprocedurale, pentru plasarea tuburilor de gastrostomie percutanată (PRG), ghidate radiologic, la pacienții cu scleroză amiotrofică laterală (ALS).

Metodă: Am urmărit, prospectiv, 10 pacienți cu ALS programați pentru instalarea PRG, la care s-au administrat blocuri paravertebrale toracice, bilateral la nivelurile T7, T8 şi T9, utilizând un amestec de $3 \mathrm{ml}$ ropivacaină $1 \%$, dexametazonă $0,5 \mathrm{mg} / \mathrm{ml}$ şi adrenalină $5 \mu \mathrm{g} / \mathrm{ml}$, pentru fiecare nivel.

Gradul de succes al blocului anestezic a fost evaluat după 10 minute. Plasarea PRG s-a realizat în departamentul de radiologie intervențională. Pacienții au fost evaluați telefonic postprocedural la 24 de ore.

Rezultate: PRG a fost plasat cu succes, la toți ce 10 pacienți, utilizând PVB toracic ca tehnică anestezică de bază. Anestezia segmentară la nivelul zonei de intervenție chirurgicală a fost obținută cu succes de la prima administrare a blocurilor. Trei pacienți au prezentat hipotensiune semnificativă după instalarea blocurilor, necesitând administrarea de bolusuri repetate de efedrină şi cristaloizi intravenos. Pacienții au prezentat un nivel ridicat de satisfacție şi au înregistrat postprocedural un somn de calitate.

Concluzii: Blocurile paravertebrale toracice au oferit anestezie procedurală satisfăcătoare şi analgezie postprocedurală, şi astfel par să reprezinte o alternativă sigură la sedare, pentru pacienții cu ALS care necesită gastrostomie percutanată.

Cuvinte cheie: blocuri paravertebrale toracice, gastrostomie percutanată, scleroză amiotrofică laterală 